\title{
Integrated food systems governance: Scaling equitable and transformative food initiatives through scholar- activist engagement
}

\author{
Colleen Hammelman a* \\ University of North Carolina at Charlotte
}

\author{
Charles Z. Levkoe ${ }^{b}$ \\ Lakehead University
}

Julian Agyeman c

Tufts University

Sanjay Kharod d

New Orleans Food \& Farm Network

\author{
Ana Moragues Faus e \\ Universitat de Barcelona
}

Elisa Munoz ${ }^{\mathrm{f}}$
New Orleans Food Policy Advisory Committee

Jose Olivag

Food Chain Workers Alliance

Amanda Wilson ${ }^{\mathrm{h}}$

Saint Paul University

Submitted January 11, 2019 / Revised April 22 and June 11, 2019 / Accepted June 12, 2019 / Published online January 7, 2020

Citation: Hammelman, C., Levkoe, C. Z., Agyeman, J., Kharod, S., Moragues Faus, A., Munoz, E., Oliva, J., \& Wilson, A. (2020). Integrated food systems governance: Scaling equitable and transformative food initiatives through scholar-activist engagement. Journal of Agriculture, Food Systems, and Community Development, 9(2), 71-86. https://doi.org/10.5304/jafscd.2020.092.003

Copyright (C) 2020 by the Authors. Published by the Lyson Center for Civic Agriculture and Food Systems. Open access under CC-BY license.

\begin{abstract}
Community-based efforts to transform food systems involve a diverse range of actors and increasingly attempt to focus on public engagement in policymaking processes. These initiatives often

a * Colleen Hammelman, Assistant Professor, Department of Geography and Earth Sciences, University of North Carolina at Charlotte; 9201 University City Blvd.; Charlotte, NC 28223 USA; +1-704-687-5916; colleen.hammelman@uncc.edu

b Charles. Z. Levkoe, Canada Research Chair in Sustainable Food Systems, Department of Health Sciences, Lakehead University; 955 Oliver Road; Thunder Bay, Ontario P7B 5E1, Canada; +1-807-346-7954; clevkoe@lakeheadu.ca

c Julian Agyeman, Professor of Urban and Environmental Policy and Planning, Tufts University, Medford, MA USA; julian.agyeman@,tufts.edu

d Sanjay Kharod, Executive Director, New Orleans Food \& Farm Network; New Orleans, LA, USA; sanjay.kharod@,noffn.org
\end{abstract}

emphasize opportunities for more participatory forms of engagement rooted in systems thinking, which recognizes the interconnections between environmental, social, and economic injustices. Similarly, food systems scholars are increasingly engaged in participatory action projects seeking to make productive linkages between academic

e Ana Moragues Faus, Ramón y Cajal Research Fellow, Universitat de Barcelona; Avinguda Diagonal, 690; 08034 Barcelona, Spain

${ }_{\mathrm{f}}^{\mathrm{E}}$ Elisa Munoz, Director, New Orleans Food Policy Advisory Committee, New Orleans, LA, USA; elisa@,nolafoodpolicy.org

g Jose Oliva, Co-Founder, Food Chain Workers Alliance, and Campaign Director, HEAL Food Alliance, Chicago, IL, USA; jose@,healfoodalliance.org

h Amanda Wilson, Assistant Professor, School of Social Innovation, Saint Paul University, Ottawa, ON, Canada; awilson@,ustpaul.ca 
research, policymakers, and community organizations in search of tangible food systems change. This collective essay, based on a roundtable discussion at the 2018 annual meeting of the American Association of Geographers (AAG) in New Orleans, describes integrated food governance processes currently underway-particularly those engaging anchoring institutions from civil society, government, and academia — to demonstrate both the promise and the challenges of networked governance efforts in pursuing more equitable food systems. In particular, we focus on how differing anchor institutions engage in translocal governance, coalition building, and adaptation. This research contributes to literature and practice on food systems governance, systems thinking, and anchoring institutions by proposing an analytical framework and providing a series of case studies of integrated governance initiatives for pursuing social and ecological justice in food systems.

\section{Keywords}

Anchoring Institutions, Integrated Governance, Engaged Scholarship, Food Systems, Policy, Scholar-Activists

\section{Introduction}

Social movement networks focusing on sustainable food systems and the connections with social and ecological justice have made significant headway over the past decades (Alkon \& Guthman, 2017; Sbicca, 2018). Beyond developing successful placebased initiatives and creating a significant impact in their local communities, food systems organizations are scaling up their activities to address policy and play a meaningful role in food systems governance. These evolving efforts respond to top-down food policy frameworks that take a fragmented approach, treat symptoms rather than structural causes, and tend to overlook on-the-ground realities, needs, and priorities of people and communities in favor of economic development (Alkon \& Guthman, 2017; Blecha \& Leitner, 2014).

Community-based efforts involving a wide range of actors across food systems frequently focus on democratic engagement in policymaking processes (Andrée, Clark, Levkoe, \& Lowitt, 2019; Desmarais, Claeys, \& Trauger, 2017; Kennedy \&
Liljeblad, 2016). These food governance networks emphasize opportunities for more participatory forms of engagement rooted in systems thinking, which recognizes the interconnections between environmental, social, and economic injustices (Ericksen, 2008). Beyond civil society, there is a growing awareness among policymakers that food systems developed from and shaped by the complex interactions between people, ecosystems, and social forces necessitate more joined-up and integrated governance responses. Similarly, food systems scholars increasingly engage in participatory action projects seeking to make productive linkages between academic research, policymakers, and community organizations in search of tangible food systems change (Anderson, Buchanan, Chang, Rodriguez, \& Wakeford, 2017; Levkoe, BremWilson, \& Anderson, 2019; Reynolds, Block, \& Bradley, 2018). Attempts at participatory and integrated food policy that engages these varied actors across food systems are not without their challenges. They require innovative governance arrangements that cross multiple geographic, scalar, and administrative boundaries, raising numerous questions about how responsibility is apportioned, priorities are set, ideas are implemented, and success is measured.

In this collective essay, based on a roundtable discussion at the 2018 annual meeting of the American Association of Geographers (AAG), we describe such integrated food governance networks-particularly those engaging actors from civil society, food policy councils, and academiato demonstrate both the promise and challenges of pursuing more equitable and sustainable food systems by addressing policy and programming. We begin with a brief review of the literature on integrated governance and anchoring institutions to establish a framework for pursuing social and ecological justice in food systems. Then we describe several case studies to demonstrate notable successes as well as challenges for implementing this framework among a range of networks. In particular, we focus on how different anchor institutions foster engagement in food systems governance through translocal networks, coalition building, and adaptation. We conclude with suggestions for taking this research, reflection, and action forward. 


\section{A Framework for Integrated Food Systems Governance}

Since the 1970s, neoliberalism has had a major impact on food systems governance by devolving responsibility from the national and regional level to municipalities, private-public partnerships, and the nonprofit sector (Peck \& Tickell, 2002). This shift from government to governance has emphasized self-governing capacities while also opening new arenas of engagement outside traditional decision-making spaces (Blue, 2009). Beyond taking on the devolved responsibility from the state, this has produced tensions surrounding the lack of resources and power available for resistance against the dominant food system (Blue, 2009; Hackworth, 2007). In response, many government laws, institutions, policies, and programs are structured in ways that separate food-related issues, thus failing to consider and address interrelationships. For example, departments of health and agriculture often have contradicting mandates, with the former directing people to eat more nutritious foods while the latter directs farmers to produce more commodity crops (Pothukuchi \& Kaufman, 2000; Thibert, 2012). At the same time, many civil society organizations and community groups tend to focus on the local context in particular places, ignoring the ways that external factors impact their work or the broader implications of their efforts. Such narrowly focused, sector-specific interventions fail to address the root causes of vulnerability. MoraguesFaus, Sonnino, \& Marsden (2017) identified five food system governance deficiencies that impinge upon food security, namely: the failure to deal with cross-scale dynamics; the inability to address persistent inequalities in food rights and entitlements; increasing geopolitical and sectorial interdependencies; power imbalances and low institutional capacities; and conflicting values of key stakeholders. In response to these challenges, many activists and scholars have called for an integrated approach to food systems governance (Barling, Lang, \& Caraher, 2002; MacRae, 2011) and a networked approach to mobilization (Constance, Renard, \& Rivera-Ferre, 2014; Levkoe, 2014) that relies on systems thinking among anchor institutions in support of sustainable transitions (Ericksen, 2008; Hinrichs, 2014). In the remainder of this section, we unpack these concepts before presenting our case studies of anchor institutions involved in integrated food systems governance.

\section{Food Systems Governance}

The concept of food systems governance can be described broadly as the establishment of rules, practices, and processes that structure the flows of power and control in the food system, from production and harvesting to consumption and waste management (Jessop, 1998; Kennedy \& Liljeblad, 2016). Governance relationships go well beyond interactions with the government, as many civil society organizations, small businesses, informal associations, and community groups play an active role in integrated governance processes, from policymaking to the provision of social services (Koc, MacRae, Desjardins, \& Roberts, 2008; Mount, 2012; Renting, Schermer, \& Rossi, 2012). Civil society networks have taken a wide range of approaches to engagement in governance, with some working closely with the state and corporate sector, while others seek to work outside formal policy and regulation, or to challenge it directly (Goodman, DuPuis, \& Goodman, 2012; Stevenson, Ruhf, Lezberg, \& Clancy, 2008).

Sustainability transitions theory has been identified by scholars as a way for policymakers to conceptualize and adopt food systems thinking by addressing the gradual, but potentially revolutionary, transition to a more sustainable state (Farla, Markard, Raven, \& Coenen, 2012; Hinrichs, 2014; Markard, Raven, \& Truffer, 2012). This scholarship examines ways to produce deep-structure changes in food systems (including, for example, energy, environment, transport, health) by recognizing the need to engage multiple private (e.g., firms and industries, consumers) and public (e.g., policymakers, civil society) actors in order to transition to a sustainable future (Geels, 2011). It calls for involving actors across social, technical, and political spheres at multiples scales in order to address wicked problems associated with transitioning complex adaptive systems such as agriculture (Dentoni Waddell, \& Waddock, 2017; Lawhon \& Murphy, 2011; Pitt \& Jones, 2016). This approach enables identification of vertical and horizontal linkages, drivers, and barriers for producing food 
system change. Some scholars (such as Marsden, 2013) have identified ways that such transitions thinking can lead to more reflexive agrifood governance in which municipalities pursue engagement across departments and with more nonstate actors in order to link agrifood concerns with health, sustainability, and antipoverty priorities. All these evolving approaches make clear the need to integrate actors across food systems in order to pursue effective food governance that can promote social and ecological justice.

\section{Anchoring Institutions That Integrate Food Systems Governance}

Strategies to influence food systems governance are more effective when pursued through networks that include a broad range of actors (e.g., academics, community organizers, producers, harvesters, etc.) and bridge sectors, scales, and places (Andrée et al., 2019). Several stakeholders-including food policy councils, civil society, and academia-serve key bridging roles in efforts to integrate food systems governance. These institutions act as anchors for networks within communities by contributing to regional economic development, rooting groups and people via diverse place-based interventions, bridging between diverse stakeholders, and making fiscal and infrastructure investments (Birch, Perry, \& Louis Taylor, 2013; Ehlenz, 2016; Perry, Wiewel, \& Menendez, 2009). For example, anchoring institutions can form coalitions with diverse expertise by establishing physical 'third' spaces for organizing and interaction, such as The Warehouse constructed by Syracuse University in its close by Near Westside neighborhood (Cantor, Englot, \& Higgins, 2013). Anchor institutions' missions, capital investments, and relationships can tie them geographically to certain places and provide opportunities for leadership in community development. They can also play a valuable role in connecting different people, supporting relationships, and sharing knowledge among and beyond specific places (Levkoe \& Stack-Cuttler, 2018; MoraguesFaus \& Sonnino, 2019).

An example of an anchoring institution that plays a bridging role and supports network collaboration for food systems governance is the food policy council. Food policy councils bring together a range of stakeholders to identify challenges and propose strategic solutions to food systems problems (Gupta et al., 2018; Harper, Shattuck, HoltGiménez, Alkon, \& Lambrick, 2009; Schiff, 2008). Taking a food systems approach, food policy councils typically exist as nongovernmental organizations but have either formal or informal relationships with municipalities and/or regional governments as they build linkages across sectors (MacRae \& Donahue, 2013; Scherb, Palmer, Frattaroli, \& Pollack, 2016). Since 2000, the number of food policy councils has increased dramatically; in 2016 there were over 300 across the United States and Canada (Sussman \& Bassarab, 2017).

There are also many other civil society organizations acting as anchoring institutions that establish and claim bridging roles in food systems governance (Carlson \& Chappell, 2015; Renting et al., 2012). For example, between 2008 and 2011, Food Secure Canada (a pan-Canadian food movement organization) acted as an anchoring institution and played a bridging role by assembling multiple local initiatives and experiences to create a pan-Canadian food policy platform rooted in food sovereignty (Levkoe \& Sheedy, 2019; People's Food Policy, 2011). Moragues-Faus and Sonnino (2019) observed in the case study of the Sustainable Food Cities Network (SFCN) in the UK that substantial power can be mobilized through translocal networks that reconfigure the food governance context away from a compartmentalized approach to a model that is integrated, cross-sectoral, and participatory. These are important developments to follow because they represent grassroots efforts to identify food systems problems and to highlight specific ways that place-based, networked initiatives anchored in civil society can scale up to affect policy (Mount, 2012).

Many scholars have also engaged in food systems governance in partnership with local food policy councils and civil society organizations as scholar-activists (see, for example, Andrée, 2019; Orozco, Ward, \& Graddy-Lovelace, 2018; Reynolds, Block, \& Bradley, 2018). Importantly, the roles of scholars, activists, and scholar-activists can be fluid and contested (Reynolds et al., 2018). Scholarly research may be undertaken by civil society organizations, while academic activities may 
have activist implications beyond the university's walls. The examples in this paper call attention to this fluidity of roles that arise in partnerships between anchoring institutions. In addition to academic and organizational partnerships that foster research on local food systems (Levkoe, Andrée et al., 2016; Romano \& Metzo, 2015), some research groups (e.g., the Johns Hopkins Center for a Livable Future ${ }^{1}$; Food: Locally Embedded, Globally Engaged $\left[\right.$ FLEdGE] ${ }^{2}$ ), and food policy councils (e.g., New Orleans Food Policy Advisory Council, as discussed below) are housed in academic institutions and are supported by academics throughout North America. In this way, universities have served as key anchors in governance networks.

\section{Methods}

To better understand the ways in which networks are using anchoring institutions to foster integrated governance for building more just and sustainable food systems, Hammelman and Levkoe organized a special session on this topic at the AAG Annual Meeting in New Orleans in April 2018. This session brought scholars and practitioners at the forefront of integrated food systems governance into a conversation about how academics, activists, policymakers, and other actors can better work together in pursuit of common goals. In doing so, it built on similar sessions organized at previous AAG meetings by members of the Geographies of Food and Agriculture Specialty Group (GFASG) (see Levkoe, Hammelman et al., 2018; Levkoe, McClintock et al., 2016). GFASG members identified leaders in food systems governance at national and local scales as participants. Scholars were selected who actively engaged civil society and policy partners (authors of this paper Agyeman and Moragues-Faus), national leaders in food policy practice (authors Oliva and Wilson), and local practitioners engaged in food system governance in New Orleans (authors Kharod and Munoz). These participants were chosen to represent diverse initiatives engaged in building networks by providing deep knowledge grounded in experience pursuing food system change.

Before the AAG session, the panelists met virtually to introduce themselves and organize and structure the discussion. Through collaboratively developing a series of guiding questions, the speakers were invited to discuss the pitfalls and possibilities of integrated food policy. After a brief introduction about how they were engaged with food policy and governance, each participant discussed the following key questions:

- What is the role of social movements and civil society groups in food systems governance?

- How can activists and academics collaborate in this work?

- What have been some notable successes, and what are the challenges?

- How has social and ecological justice been addressed by attempts at integrated food policy?

Following short presentations, the panel engaged in discussion with the audience. ${ }^{3}$

The roundtable discussion was recorded, transcribed, and reviewed by Hammelman and Levkoe to identify key themes and illustrative case studies. The remaining authors further reflected on the case studies and contributed to the framework, analysis of the major themes, and conclusions that make up the remainder of this essay. Several sections reflect on the specific work of an organization or experience of a co-author, but overall the paper represents a synthesis of collective reflections. As such, we refrain from using first-person in favor of the collective first-person plural (we) representations of this work. The following section presents case studies to illustrate the bridging roles of anchoring

\footnotetext{
${ }^{1}$ For more information on the Johns Hopkins Center for a Livable Future, see https://www.jhsph.edu/research/centers-andinstitutes/johns-hopkins-center-for-a-livable-future/index.html

${ }^{2}$ For more information the FLEdGE research network, see https://fledgeresearch.ca/

${ }^{3}$ The 100-minute session, titled Activist-Scholar Roundtable-Toward Integrated Food Systems Governance: Policy, Justice, and Social Movements, was open to all conference attendees and was promoted by the GFASG. Approximately 75 people attended the roundtable presentation and participated in the ensuing discussion.
} 
institutions, particularly food policy councils, civil society, and universities, in integrated food systems governance. The case studies also demonstrate the importance of flexibility and adaptation when seeing success and experiencing challenges. These examples are instructive for both scholarship and emerging practitioners pursuing integrated food systems governance through anchor institutions.

\section{Integrated Food Systems Governance Case Studies}

This section presents a series of case studies that collectively demonstrate the current role and potential opportunities of anchor institutions in pursuing integrated food systems governance. We present the case studies in categories relating to food policy councils, civil society organizations, and universities. We begin with examples of the roles of each of these actors in anchoring institutions before considering ways in which anchoring institutions themselves pursue networking opportunities to scale up local efforts and impact governance. Finally, we consider the possibilities and pitfalls that arise in this work.

\section{Perspectives From Within Anchoring Institutions}

Anchoring institutions can play different yet complementary roles in governance networks focused on bridging diverse perspectives, sectors, and scales. In some networks, food policy councils can provide direct linkages to government, while civil society engages with grassroots actors and communities, and academics provide research and critical perspectives, and scale up the work of activists. These roles vary by network and context and are often fluid and interconnected. Each of these actors serves an anchoring role through bridging between stakeholders in pursuit of systemic change. In the following case studies, we discuss the ability of such anchoring institutions to empower communities, connect with those most affected by food policy, and foster ongoing coalitions.

Food Policy Councils: New Orleans Food Policy Advisory Council ${ }^{4}$

The New Orleans Food Policy Advisory Council
(FPAC) was officially established in 2007 through a resolution from the New Orleans City Council. Prior to that resolution, the Tulane Prevention Research Center (PRC) received a grant from the Robert Wood Johnson Foundation to establish the FPAC with the goal of increasing food access. The initial collaboration between businesses, civil society organizations, and individuals revealed the vast need for fresh and healthy food following Hurricane Katrina, and so the collaborators pursued programs such as the Fresh Food Retailer Initiative in response. Today, as an official advisory body to the New Orleans City Council, the FPAC is a group of 28 organizations, businesses, advocates, and individuals working in three areas: food access, food production, and food business development. The FPAC operates as an independent organization with the support of all member organizations, including the Tulane PRC, which provides administrative and fiscal support in addition to maintaining a voting seat. The FPAC aims to foster policy change and bridge diverse stakeholders in order to gain traction on food systems concerns. In one successful initiative, the original FPAC founders studied community needs and best practices related to food access and issued a set of recommendations to the city, specifically to attract grocers and other food stores back to the city and encourage them to make fresh food available. Following these recommendations, the Fresh Food Retailer Initiative was established in 2011. This initiative was designed to incentivize fresh food access by providing low-cost loans and grants to grocers.

In 2017, the FPAC conducted a food policy assessment and again produced a set of recommendations to policymakers and partners. The assessment was completed by bridging knowledge across community organizations and neighborhoods. It included recommendations to support infrastructure for urban farms and to recognize urban agriculture as a strategy for collecting rainwater and mitigating flooding. These recommendations were eventually included in the City Planning Commission's master plan. One of the major challenges to this has been ensuring that the policies that are recommended are enacted in a way that addresses the

${ }^{4}$ For more information on the New Orleans Food Policy Advisory Council, see http://nolafoodpolicy.org/ 
realities of the local context and involves community members. The key to this is ensuring that the voice of the community is heard in advocating for the policies that will affect them, their families, and all residents of New Orleans. One way that FPAC pursues this is through regular participation in community and neighborhood association meetings. For example, an urban agriculture working group gathered input throughout the city by presenting at these meetings about its work and seeking feedback on urban agriculture initiatives, awareness of such efforts, and improvements that can be made. Through those consultations, FPAC seeks diverse opinions about specific policy proposals, such as enabling urban farmers to sell products directly on site. As it works to bridge the gap between the people making policy and those most affected, the FPAC strives to understand ways to envision a community-driven approach to food governance.

\section{Civil Society: Food Chain Workers Alliance Good Food} Purchasing Policy ${ }^{5}$

The Food Chain Workers Alliance (FCWA) was established in 2008 as a binational coalition of food worker organizations, which includes farmworkers, processing workers, workers in the transportation and warehousing sectors, as well as restaurants and grocery stores. Together it represents roughly 350,000 workers in the United States and Canada. Early on, the FCWA realized that its work should not be trying to convince sustainability or local economy organizations that workers should be at the forefront of their work. Instead, it was about working together with these organizations as part of an anchored, systems approach. The FCWA agreed that in order to create a broad-based network, it had to come up with something creative that would address the food system as a whole. The result was the Good Food Purchasing Policy, which co-director Joann Lo helped to develop as a co-facilitator of a Los Angeles Food Policy Council working group.

The Good Food Purchasing Policy is a procurement policy that can be adopted by large pub- lic institutions that consume substantial amounts of food, such as school districts (for example, the Los Angeles Unified School District, which has adopted the GFPP, purchases almost US $\$ 150$ million of food every year). Through education and negotiation with other organizations working to address issues in the food system, a campaign was launched to encourage widespread adoption of the GFPP. It was important to FCWA to ensure that people at the grassroots remained in leadership roles and were directly engaged in carrying forward these campaigns. Once the GFPP is adopted, the institution agrees to abide by a set of five value categories representing the interconnections in food systems: human health, environmental sustainability, animal welfare, local economies, and labor. Each adoptee agrees to comply with a baseline on all five categories representing the integrated impacts of the policy. For municipalities, the values are written into the contract language that goes out to the food providers. To date, the GFPP has been formally adopted in five cities: Austin, Chicago, Los Angeles, Oakland, and San Francisco. Following the successful development and passage of the GFPP in Los Angeles, the Center for Good Food Purchasing was established to further manage the growing program. Be it school systems or municipalities, the GFPP is taking over public space with a systems-based approach to food rooted in social and ecological justice.

Key to the GFPP's success is the FCWA's multisector, multiracial, demographically representative coalition in every city. In Los Angeles, the first city to pass it (in 2012), the coalition remained active. When some of the major industrial food corporations came up for contract renewal with the Los Angeles Unified School District, the coalition worked to ensure that the GFPP was enforced. This approach to governance is an innovative model led by a civil society organization as the anchor institution. In that role, the FCWA contributes to regional economic development while also bridging between diverse stakeholders by building and sustaining coalitions. Beyond the success of the GFPP itself, the coming together of

\footnotetext{
${ }^{5}$ For more information on the Food Chain Workers Alliance's Good Food Purchasing Policy, see https:// foodchainworkers.org/?page id $=4235$
} 
such a diverse group of people around the FCWA planted a seed for future food system change.

\section{Universities: Professor of the Practice}

At Tufts University's Department of Urban and Environmental Policy and Planning, author Agyeman established and hired a "professor of the practice" in 2008 with the goal of fostering longterm engagement between the university and community projects. A professor of the practice is someone who has achieved significant accomplishments in community-based work and continues active community involvement while also holding an academic appointment. This initiative demonstrates the potential of a university to be an anchor institution where academics are responsive and engaged in their communities. Agyeman's initial concern was that urban planners often invite community organizations into their classes, thank them, write them a check for an honorarium, and then say goodbye, then repeat this pattern year after year. This is not a relationship with a community but is simply having a community representative sporadically provide input into a class. Penn Loh, a former executive director of Alternatives for Community and Environment (ACE), a Boston-based environmental justice organization, was brought on as the first professor of the practice. This enabled the development of a Community Engagement Strategy for Tufts' Urban and Environmental Policy and Planning (UEP) program. It also bolstered a growing relationship with community organizations as allies rather than just as producers of knowledge to be called on intermittently. Ultimately, having the professor of the practice position allowed Tufts to explore ways to build power in communities to give them a stronger voice in decision making and governance. Loh is a leader in the environmental and food justice world in Boston. On a practical level, this meant that academic faculty and students benefited in terms of access to community-based projects in both the core and elective curriculum. For example, the UEP program requires a studio class in the first year, where students work in small groups with local organizations. Now there are ongoing, yearto-year relationships with community organizations throughout the core curriculum. These projects, integrated into the studio class, involve coresearching community-generated questions. For example, this work has contributed to an emerging food solidarity economy project in Boston, focusing on sharing food resources (Loh \& Agyeman, 2019). The project has involved Loh, Agyeman, student researchers, and a range of community organizations in Boston's vibrant food justice and urban agriculture communities. The empirical data for the project was drawn from secondary sources and qualitative interviews by students as well as from Loh and Agyeman's direct engagement with practitioners and projects. Building on existing urban food-sharing practices in Boston's lower-income neighborhoods, the initiative has demonstrated the emergence of an as yet uncoordinated network of food system actors who are building solidarity financing that includes food justice and encompasses all parts of the food system (e.g., taking collective ownership of land, establishing shared growing spaces, developing shared facilities for food businesses, and launching a worker-owned food recycling cooperative). The actors are driven by desires for transformation and are decommodifying the food system and increasing the urban food commons.

These networked efforts pursued by the New Orleans FPAC, FCWA, and Tuft's professor of the practice recognize and enhance people's roles in food systems governance with communities as producers of knowledge and simultaneously enrich the university's programs, while students, in turn, give back to communities. In doing so, these sectors serve as anchor institutions, creating bridges that foster scholar-activist projects.

\section{Bridging Network. Anchors}

While each of the anchoring institutions described above generated successes individually, their reach and impact at a systems-level are enhanced through connecting their work. This includes building partnerships to implement research and projects in pursuit of sustainable food systems transitions. This section provides illustrative case studies to demonstrate what partnerships look like that strive to break down the barriers between siloed policy actors and provide a new, integrated lens on food system concerns. 
Research Informing Practice and Policy: New Orleans Farm and Food Network $6 / 596$ Acres $^{7}$

The New Orleans Farm and Food Network (NOFFN) was established in 2002 to support the building of a new food economy through increasing markets for farmers, incubating farms, and training new farmers. Its biggest accomplishment has been the ability to catalyze a diverse population that is actively engaged in efforts to ensure that the regional food system is more responsive to social and ecological justice. One way it accomplishes this goal is by serving as a bridge in building partnerships among unlikely allies (such as the New Orleans Business Alliance) involved in the food system.

Learning from its work with activists and scholars and seeing the value of coordination, NOFFN began research projects in partnership with academic and activist scholars to answer questions and respond to problems that arose. For example, NOFFN wanted to create a map of vacant lots that were available through the redevelopment authority. This was part of an Urban Farming Toolkit to assist urban farmers in accessing vacant land. It included paperwork guidance (water access, property liability, farm registration, landowner/tenant farmer agreements, etc.) along with business guidance (market farming, loans, grants). It began by creating a Google map, but quickly realized it did not contain the right information and things were changing so fast that it quickly became out of date. NOFFN reached out to a group called 596 Acres focused on developing tools for land access advocacy. The organization came up with a way of harvesting, representing, and sharing publicly available data on vacant land, in an open and transparent way. This collaborative project forced the redevelopment authority to explain how they were going to dispose of land for farmers. The results also contributed to the Urban Farming Toolkit. The first step in this project was coordinating among actors to initiate researchfinding publicly available data and creating a mechanism, which in this case is an app that makes this data accessible to farmers. The second part was having a community organization that was willing to be the advocate for increasing land access. This case study of the NOFFN demonstrates how building partnerships to affect governance can engage in community-based research and work with community stakeholders, but also be adaptable to rapidly changing environments.

\section{Partnerships to Enhance Food Policy Engagement: Food Secure Canada 8}

Food Secure Canada (FSC) is a civil society organization that works to advance the interrelated goals of a healthy, just, and sustainable food system across Canada. As a national network of both individual and organizational members, FSC operates as an intermediary between grassroots food movement organizations and activists on the one hand, and federal policy-makers and government officials on the other, linking grassroots efforts to developments and openings for advocacy at the federal level. Creating a national food policy has been one of the core campaign objectives of FSC over the past decade. There is broad acknowledgment, not only with Canada's food movements, but also across the food system, that the current approach to food policy in Canada is not working, especially for those most marginalized. Recognizing that siloed departments, each with their own objectives and priorities, can only go so far, FSC members argued that an integrated approach was needed that would connect food-related concerns in health and well-being, agriculture, and the environment. New prospects for integrated food systems governance action emerged in 2015 when the Liberal party was elected, offering a much more progressive political agenda. The mandate letter to the new federal minister of agriculture announced a commitment to developing a national food policy and officially began consultations in 2017 via an online survey, a National Food Summit with over 300 participants, regional stakeholder roundtables, along with various meetings and presentations by government officials. In September 2018, the government shared a summary of the feedback provided

\footnotetext{
${ }^{6}$ For more information on New Orleans Farm and Food Network, see https://www.noffn.org/

${ }^{7}$ For more information on 596 Acres, see http://596acres.org/

${ }^{8}$ For more information about Food Secure Canada, see https://foodsecurecanada.org/
} 
through the consultations, and in the summer of 2019 released the Food Policy for Canada (Government of Canada, 2019).

FSC's approach to this national food policy process has been twofold. First, it engaged directly in the consultation process in an attempt to advance strategic policy principles to provide real gains or useful language to build on in the future. However, FSC's activities were not solely about policy advocacy in the traditional sense. Its focus has also been on movement building, an equally, if not more, important task. Movement building occurred through an intentional focus, not only on the final food policy, but also on mobilizing and engaging organizations and individuals in an attempt to prefigure a participatory and democratic approach to food systems governance, and strengthening the capacity of new and existing networks. This approach envisions policy as not just something that is achieved on paper, but as a space that is created to build relationships and capacity and imagine a different kind of food system.

\section{Reflections on Possibilities and Pitfalls of Integrated Food Systems Governance Through Networks}

Operating within integrated governance networks presents many possibilities but is also challenging. It can be messy, uncomfortable, and at times it is not possible to manage tensions. In this section, we reflect on the experiences of anchoring institutions using networks to pursue transformational change via integrated governance mechanisms. In particular, the case studies presented here call for building more creative structures that recognize the various roles played by scholar-activists in the broad categories of civil society, academia, and food policy; recognizing the competing priorities and limitations for each of these actors; and through both ensuring that research can lead to mutually beneficial and actionable outcomes.

\section{Building creative structures}

Diversity and creativity are key ideas in building networks. Within food movements, the many different needs and visions do not always work well together. It is important to recognize the different roles that these stakeholders - civil society, academia, and food policy councils - can play in transforming the dominant food system. Some (such as grassroots advocacy groups or tenured professors) can pursue more radical action and question state actions or strategies, while others (such as government-based food policy councils) must pursue reform from within and tread more lightly. Confrontational activities can be as important as those that involve negotiating public policies with governments. In some cases, academics can also provide an important critical voice. Civil society organizations that work in partnership with governments or seek to influence policy decisions do not always feel free to critique government positions. Academics can play an important role in articulating a more critical or long-term vision of food system transformation and in occupying an adversarial space that is difficult for some civil society organizations or food policy councils. For example, during the consultation process for developing a national food policy for Canada, it was useful to have the voices of academics and researchers alongside those of civil society organizations, at times echoing the positions of FSC and at times pushing even further in their articulation of food sovereignty and decolonization. This exemplifies the ways that each anchor institution in a network can leverage its voice.

Embracing a diversity of positions calls for a more fluid and flexible understanding of governance. That is, interactions and alliances that have not established who can participate or how decisions are made are still valuable and can contribute to a transformative project. Unstructured interactions range from campaigns that connect people across the globe to creating spaces of deliberation and networking. For example, the Oxford Real Farming Conference is a space where activists, organizations, public institutions, small farmers, and entrepreneurs come together to address food system challenges in the UK and beyond. ${ }^{9}$ These unstructured interactions can be facilitated by individuals, groups, or institutions, which actively create emerging and fluid spaces for wider transformation. Relationships can then be fragile, time-

\footnotetext{
${ }^{9}$ For more information on the Oxford Real Farming Conference, see http://orfc.org.uk/
} 
bound and even confrontational. However, they can still hold key values such as the capacity to celebrate the diversity of eaters in the food system and allow surfacing of conflicts and new avenues for their resolution.

\section{Recognizing competing priorities and limitations}

Just as different institutions pursue different tactics for change, they may also encounter competing priorities and limitations to further collaboration. The rewards for civil society engagement (e.g., galvanizing government and public interest in a topic) do not always align with the rewards for academic engagement (e.g., peer-reviewed publications). Envisioning projects seeking such different outcomes (and timelines) can create tension, while recognizing the value of different types of research projects opens up more avenues for collaborative action.

For FSC, there were many benefits that emerged from the food policy consultation process, some of which remain valuable regardless of the final policy outcomes. The opportunity to contribute to the creation of a national food policy galvanized not only the food movement but also public interest in food issues more broadly. Based on an analysis of the shifts in the government's discourse and stated priorities for the national food policy, FSC (alongside other civil society actors) was successful in pushing the government to adopt more progressive and substantive language (e.g., around food security and land preservation), as well as to force them to include elements in the food policy not present in its original presentation (e.g., the right to food, Indigenous food sovereignty). However, despite these gains, the national food policy appears to remain entrenched in many of the previous divisions that have plagued food policy, thus failing to outline a clear path forward that will integrate health, economic sustainability, and environmental protection.

Similarly, the New Orleans FPAC's 2017 food policy assessment and related recommendations to city council strengthened its relationships with local government. In 2018, city council recognized FPAC's achievements in bridging sectors and research across the food system by designating it as an official advisory body. As the only organization from the food sector serving this role, FPAC makes recommendations to the city council via consultation with individual council members, in quarterly reports, and through a public meeting at the end of each year. It also produces public reports and holds public meetings on food and agriculture matters. These research and policy products are developed by the FPAC as a bridge among many different food system stakeholders, many of which rely on FPAC to be the policy voice for its collaboratives.

In addition to civil society research products, scholar-activist collaborations often seek academic publications (such as this paper). These differing products and related priorities highlight that the rewards for academic work may not align with those of civil society partners. Many academic partners must pursue peer-reviewed publications from such projects in order to receive recognition for the work within their institutions. Yet, civil society partners may find those goals and timelines to be burdensome. In response, a number of academic journals have developed to encourage and support diverse types of contributions. For example, Local Environment (co-founded by Agyeman in 1996) provides different avenues for publication, including a regular column that is not peer-reviewed (the Journal of Agriculture, Food Systems, and Community Development and the Canadian Food Studies/La Revue canadienne des études sur l'alimentation offer similar types of opportunities). With those pieces, practitioners can have their work published fairly quickly, in contrast to the lengthy timeline of peer review and editing for traditional articles. Including these opportunities reflects Local Environment's aim to create a dialogue between academics and practitioners through valuing nontraditional publication platforms. While these are positive developments, more effort should be made to include researchers and practitioners positioned outside the university in the publication and review process (Levkoe, Schembri, $\&$ Wilson, 2018), and more academic value needs to be placed on public scholarship (e.g., tweets, blogs, media concepts) that galvanizes public interest in a topic.

Finally, academia is still seen by many civil society practitioners as a privileged space where exploitation-in the form of limited funding and 
recognition for community-engaged alternative food systems research — contributes to reinforcing dominant discourses around food system challenges and solutions. Furthermore, academic spaces are contentious spaces where notions of "valid knowledge" are disputed in ways that empower or disempower particular actors and narratives. For these reasons, it is important to build alliances with social movements that help transform academic institutions. Among others, this includes asking what types of knowledge are higher education institutions producing and rewarding? Are universities a public good or a business that needs to generate revenues? Many academics are now engaged in creating trust and working relationships with civil society in a productive way, as evidenced by the case studies presented in this collective essay. This is also evident in action research projects engaging students in co-producing knowledge and actively changing the local foodscape where they live (such as the Food Research Collective at Cardiff University ${ }^{10}$ ). However, there are many civil society groups that could benefit from action research and co-production processes that do not currently have access to that support. It is urgent to reflect on what kinds of needs are being addressed, who is involved in partnerships, and why. This approach demands a more careful and caring academia that broadens its scope and mission and engages with those places that are out of reach, at the margins, or within everyday and mundane initiatives.

\section{Producing actionable outcomes}

Differing civil society and academic incentives also encounter challenges in producing material that spurs concrete, tangible change. In post-Katrina New Orleans, there were many assessments, research studies, and surveys produced by researchers within and outside of the city (sometimes surveying the same neighborhood simultaneously). Unfortunately, much of the research produced sits on library shelves or was published in journals that are inaccessible to the community. This reinforces a sense of distrust toward academic research. The
New Orleans FPAC is housed within an academic institution and was founded within Tulane University's Prevention Research Center. It continues to struggle to ensure that its work is relevant, informative, and accessible to food systems decisionmakers. For instance, the FPAC recently completed a series of food policy assessments asking key informants, partners, stakeholders, and community groups about the policy gaps and barriers they encounter. The information collected through these assessments made apparent that many people do not understand what food policy is and how it affects their lives. Addressing these concerns, the collaborative committee used the assessment data to create a food system strategic plan (MunozMiller, n.d.). The assessment process produced a concrete list of related recommendations on which FPAC and its partners are committed to act. It also raised the FPAC's profile with city council, resulting in the aforementioned resolution authorizing the FPAC as an official advisory body. Food policy councils, civil society organizations, and academic institutions can serve important anchoring roles in bringing to the forefront actions led by those most affected by the negative impacts of the dominant food systems. However, scaling up such work should also serve as a bridge to stakeholders that can produce actionable outcomes.

\section{Conclusion}

This paper describes several efforts of integrated food system governance through which food policy councils, civil society, and academics serve as anchoring institutions pursuing systems-level transitions to more just and sustainable food systems. In doing so, we presented case studies of networked approaches from the perspective of different anchoring institutions, the roles that actors can play in these networks, and the possibilities and pitfalls encountered in this work. Each case study provides dimension to our framework of integrated food systems governance, while also providing examples for activists and scholars seeking to establish collaborations for food system change.

\footnotetext{
${ }^{10}$ For more information about the Food Research Collective, see https://foodresearch.org.uk/publications/participatory-action-research-with-local-communities-transforming-our-food-system/
} 
Food policy councils, civil society organizations, and academic institutions can serve as anchoring institutions to respond to food crises at multiple scales through integrated food systems governance. These networks aim to build coalitions fostering healthy food retail (e.g., New Orleans FPAC) and ensure fair labor and accountability in purchasing chains (e.g., FCWA's Good Food Purchasing Policy) via ongoing partnerships between academics (e.g., the professor of the practice position) and civil society (e.g., creating maps of public data to support redistribution of vacant land), and by networking across all of these actors through public consultations to shift the dialogue on regional and national food policies.

We are convinced that the transition to more just and sustainable food systems will not occur through individually focused efforts. Instead, it will require collaboration among the many sectors and actors that produce and reproduce food systems on a daily basis. We present this collective essay as an invitation to our partners throughout food systems to find avenues to collaborate and build on the contributions made by anchoring institutions so as to have a greater impact on creating food system governance that is responsive to the communities that are most affected by the crisis.

\section{References}

Alkon, A., \& Guthman, J. (Eds.). (2017). The new food activism: Opposition, cooperation, and collective action. Oakland: University of California Press. https://doi.org/10.1525/california/9780520292130.001.0001

Anderson, C., Buchanan, C., Chang, M., Rodriguez, J. S., \& Wakeford, T. (2017). Everyday experts: How people's knowledge can transform the food system. Coventry, UK: Coventry University, The Centre for Agroecology, Water and Resilience. https://doi.org/10.18552/9781846000751

Andrée, P., Clark, J. K., Levkoe, C. Z., \& Lowitt, K. (Eds.). (2019). Civil society and social movements in food system governance. New York: Routledge. https://doi.org/10.4324/9780429503597

Barling, D., Lang, T., \& Caraher, M. (2002). Joined-up food policy? The trials of governance, public policy and the food system. Social Policy \& Administration, 36(6), 556-574. https://doi.org/10.1111/1467-9515.t01-1-00304

Birch, E., Perry, D., \& Louis Taylor, H. Jr. (2013). Universities as anchor institutions. Journal of Higher Education Outreach and Engagement, 17(3), 7-15.

Blecha, J., \& Leitner, H. (2014). Reimagining the food system, the economy, and urban life: New urban chicken-keepers in US cities. Urban Geography, 35(1), 86-108. https://doi.org/10.1080/02723638.2013.845999

Blue, G. (2009). On the politics and possibilities of locavores: Situating food sovereignty in the turn from government to governance. Politics and Culture, 2009(2), 69-79. Retrieved from https://politicsandculture.org/2010/10/27/on-thepolitics-and-possibilities-of-locavores-situating-food-sovereignty-in-the-turn-from-government-to-governance/

Cantor, N., Englot, P., \& Higgins, M. (2013). Making the work of anchor institutions stick: Building coalitions and collective expertise. Journal of Higher Education Outreach and Engagement, 17(3), 17-46. Retrieved from https://ojs01.galib.uga.edu/iheoetest/article/download/2525/2524

Carlson, J., \& Chappell, M. J. (2015). Deepening food democracy. Institute of Agriculture and Trade Policy. Retrieved from https://www.iatp.org/documents/deepening-food-democracy

Constance, D. H., Renard, M.-C., \& Rivera-Ferre, M. G. (Eds.). (2014). Alternative agrifood movements: Patterns of convergence and divergence. London: Emerald. https://doi.org/10.1108/S1057-192220140000021018

Dentoni, D., Waddell, S., \& Waddock, S. (2017). Pathways of transformation in global food and agriculture systems: Implications from a large systems change theory perspective. Environmental Sustainability, 29, 8-13. https://doi.org/10.1016/i.cosust.2017.10.003

Desmarais, A. A., Claeys, P., \& Trauger, A. (Eds.). (2017). Public policies for food sovereignty: Social movements and the state. New York: Routledge.

Ehlenz, M. (2016). Neighborhood revitalization and the anchor institution: Assessing the impact of the University of Pennsylvania's West Philadelphia Initiatives on University City. Urban Affairs Review, 52(5), 714-750. https://doi.org/10.1177/1078087415601220 
Ericksen, P. J. (2008). Conceptualizing food systems for global environmental change research. Global Environmental Change, 18(1), 234-245. https://doi.org/10.1016/i.gloenvcha.2007.09.002

Farla, J., Markard, J., Raven, R., \& Coenen, L. (2012). Sustainability transitions in the making: A closer look at actors, strategies and resources. Technological Forecasting \& Social Change, 79, 991-998. https://doi.org/10.1016/i.techfore.2012.02.001

Geels, F. (2011). The multi-level perspective on sustainability transitions: Responses to seven criticisms. Environmental Innovation and Societal Transitions, 1, 24-40. https://doi.org/10.1016/j.eist.2011.02.002

Goodman D., DuPuis, E. M., \& Goodman, M. K. (2012). Alternative food networks: Knowledge, place and politics. London \& New York: Routledge. https://doi.org/10.4324/9780203804520

Government of Canada. (2019). Food Policy for Canada. Retrieved December 2019 from https://www.canada.ca/en/campaign/food-policy.html

Gupta, C., Campbell, D., Munden-Dixon, K., Sowerwine, J., Capps, S., Feenstra, G., \& Kim, J. V. S. (2018). Food policy councils and local governments: Creating effective collaboration for food systems change. Journal of Agriculture, Food Systems, and Community Development, 8(Suppl. 2), 11-28. https://doi.org/10.5304/jafscd.2018.08B.006

Hackworth, J. (2007). The neoliberal city: Governance, ideology and development in American urbanism. Cornell University Press.

Harper, A., Shattuck, A., Holt-Giménez, E., Alkon, A., \& Lambrick, F. (2009). Food policy councils: Lessons learned. Food First: Institute for food and development policy. Retrieved from https://foodfirst.org/publication/food-policy-councils-lessons-learned/

Hinrichs, C. C. (2014) Transitions to sustainability: A change in thinking about food systems change? Agriculture and Human V alues, 31(1), 143-155. https://doi.org/10.1007/s10460-014-9479-5

Jessop, B. (1998). The rise of governance and the risks of failure: The case of economic development. International Social Science Journal, 50(155), 29-45. https://doi.org/10.1111/1468-2451.00107

Kennedy, A., \& Liljeblad, J. (Eds.). (2016). Food systems governance: Challenges for justice, equality and human rights. New York: Routledge.

Koc, M., MacRae, R., Desjardins, E., \& Roberts, W. (2008). Getting civil about food: The interactions between civil society and the state to advance sustainable food systems in Canada. Journal of Hunger \& Environmental Nutrition, 3(23), 122-144. https://doi.org/10.1080/19320240802243175

Lawhon, M., \& Murphy, J. (2011). Socio-technical regimes and sustainability transitions: Insights from political ecology. Progress in Human Geography, 36(3), 354-378. https://doi.org/10.1177/0309132511427960

Levkoe, C. Z. (2014). The food movement in Canada: A social movement network perspective. Journal of Peasant Studies, 41(3), 385-403. https://doi.org/10.1080/03066150.2014.910766

Levkoe, C. Z., Andrée, P., Bhatt, V., Brynne, A., Davison, K. M., Kneen, C., \& Nelson, E. (2016). Collaboration for transformation: Community-campus engagement for just and sustainable food systems. Journal of Higher Education, Outreach and Engagement, 20(3), 23-61. https://openjournals.libs.uga.edu/jheoe

Levkoe, C. Z., Brem-Wilson, J., \& Anderson, C. R. (2019). People, power, change: Three pillars of a food sovereignty research praxis. The Journal of Peasant Studies, 46(7), 1389-1412. https://doi.org/10.1080/03066150.2018.1512488

Levkoe, C. Z., Hammelman, C., Craven, L., Dandy, G., Farbman, J., Harrison, J., \& Mount, P. (2018). Building sustainable communities through food hubs: Practitioner and academic perspectives. Journal of Agriculture, Food Systems, and Community Development, 8(2), 107-122. https://doi.org/10.5304/jafscd.2018.082.008

Levkoe, C. Z., McClintock, N., Minkoff-Zern, L. A., Coplen, A., Gaddis, J., Lo, J., . . Weiler, A. (2016). Forging links between food chain labor activists and academics. Journal of Agriculture, Food Systems, and Community Development, 6(2), 129-142. https://doi.org/10.5304/jafscd.2016.062.009

Levkoe, C. Z., Schembri, V., \& Wilson, A. D. (2018). Community-academic peer review: Prospects for strengthening community-campus engagement and enriching scholarship. Engaged Scholar Journal: Community-Engaged Research, Teaching, and Learning, 4(2), 1-20. https://doi.org/10.15402/esj.v4i2.61745

Levkoe, C. Z., \& Sheedy, A. (2019). A people-centred approach to food policy making: Lessons from Canada's People's Food Policy project. Journal of Hunger \& Environmental Nutrition, 14(3), 318-338. https://doi.org/10.1080/19320248.2017.1407724 
Levkoe, C. Z., \& Stack-Cutler, H. (2018). Brokering community-campus partnerships: An analytical framework. Gateways: International Journal of Community Research and Engagement, 11(1), 18-36. https://doi.org/10.5130/ijcre.v11i1.5527

Loh, P., \& Agyeman, J. (2019). Urban food sharing and the emerging Boston food solidarity economy. Geoforum,99, $213-$ 222. https://doi.org/10.1016/j.geoforum.2018.08.017

MacRae, R. (2011). A joined-up food policy for Canada. Journal of Hunger \& Environmental Nutrition, 6(4), $424-457$. https://doi.org/10.1080/19320248.2011.627297

MacRae, R., \& Donahue, K. (2013). Municipal food policy entrepreneurs: A preliminary analysis of how Canadian cities and regional districts are involved in food system change. Toronto Food Policy Council. Retrieved from https://foodsecurecanada.org/resources-news/resources-research/municipal-food-policy-entrepreneurs

Markard, J., Raven, R., \& Truffer, B. (2012). Sustainability transitions: An emerging field of research and its prospects. Research Policy, 41, 955-967. https://doi.org/10.1016/j.respol.2012.02.013

Marsden, T. (2013). From post-productionism to reflexive governance: Contested transitions in securing more sustainable food futures. Journal of Rural Studies, 29, 123-134. https://doi.org/10.1016/j.jrurstud.2011.10.001

Moragues-Faus, A., \& Sonnino, R. (2019). Re-assembling sustainable food cities: An exploration of translocal governance and its multiple agencies. Urban Studies, 56(4), , 778-794. https://doi.org/10.1177/0042098018763038

Moragues-Faus, A., Sonnino, R., \& Marsden, T. (2017). Exploring European food system vulnerabilities: Towards integrated food security governance. Environmental Science \& Policy, 75, 184-215.

https://doi.org/10.1016/j.envsci.2017.05.015

Mount, P. (2012). Growing local food: Scale and local food systems governance. Agriculture and Human Values, 29(1), 107-121. https://doi.org/10.1007/s10460-011-9331-0

Munoz-Miller, E. (n.d.). Policy matters: Assessing the policy gap and opportunities in the New Orleans Food System. New Orleans Food Policy Advisory Committee. Retrieved from http://www.nolafoodpolicy.org/uploads/nolafpac-food-policy-assessment.pdf

Orozco, A. A., Ward, A., \& Graddy-Lovelace, G. (2018). Documenting USDA discrimination: Community-partnered research on farm policy for land justice. ACME: An International E-Journal for Critical Geographies, 17(4), $999-1023$. Retrieved from https://acme-journal.org/index.php/acme/article/view/1514

Peck, J., \& Tickell, A. (2002). Neoliberalizing space. In N. Brenner \& N. Theodore (Eds.), Spaces of neoliberalism: Urban restructuring in Western Europe and North America (pp. 33-57). Oxford, UK: Blackwell. https://doi.org/10.1002/9781444397499.ch2

People's Food Policy. (2011). Setting the table: A people's food policy for Canada. Ottawa: People's Food Policy Project. Retrieved from https://foodsecurecanada.org/people-food-policy

Perry, D. C., Wiewel, W., \& Menendez, C. (2009). The university's role in urban development: From enclave to anchor institution. Land Lines, July. Cambridge, MA: Lincoln Institute of Land Policy..

Pitt, H., \& Jones, M. (2016). Scaling up and out as a pathway for food system transitions. Sustainability, 8(10), 1025. https://doi.org/10.3390/su8101025

Pothukuchi, K., \& Kaufman, J. (2000). The food system: A stranger to the planning field. Journal of the American Planning Association, 66(2), 113-124. https://doi.org/10.1080/01944360008976093

Renting, H., Schermer, M., \& Rossi, A. (2012). Building food democracy: Exploring civic food networks and newly emerging forms of food citizenship. International Journal of Sociology of Agriculture and Food, 19(3), $289-307$. https://ijsaf.org/index.php/ijsaf

Reynolds, K., Block, D., \& Bradley, K. (2018). Food justice scholar-activism and activist-scholarship: Working beyond dichotomies to deepen social justice praxis. ACME: An International E-Journal for Critical Geographies, 17(4), $988-998$. Retrieved from https://acme-journal.org/index.php/acme/article/view/1735

Romano, V., \& Metzo, K. (2015). State of the plate, Charlotte \& Mecklenburg. Charlotte-Mecklenburg Food Policy Council. Retrieved from http://www.charlottefoodpolicy.org/uploads/6/5/3/0/65305201/2015 state of the plate.pdf

Sbicca, J. (2018). Food justice now: Deepening the roots of social struggle. Minneapolis: University of Minnesota Press. https://doi.org/10.5749/j.ctv3dnnrt 
Scherb, A., Palmer, A., Frattaroli, S., \& Pollack, K. (2016). Exploring food system policy: A survey of food policy councils in the United States. Journal of Agriculture, Food Systems, and Community Development, 2(4), 3-14. https://doi.org/10.5304/jafscd.2012.024.007

Schiff, R. (2008). The role of food policy councils in developing sustainable food systems. Journal of Hunger \& Environmental Nutrition, 3(2-3), 206-228. https://doi.org/10.1080/19320240802244017

Stevenson, G. W., Ruhf, K., Lezberg, S., \& Clancy, K. (2008). Warrior, builder, and weaver work. In C. C. Hinrichs \& T. A. Lyson (Eds.), Remaking the North American food system: Strategies for sustainability (pp. 33-62). Lincoln: University of Nebraska Press.

Sussman, L., \& Bassarab, K. (2017). Food policy council report 2016. Retrieved from the Johns Hopkins Bloomberg School of Public Health website: https://assets.jhsph.edu/clf/mod clfResource/doc/FPC\%20Report\%202016 Final.pdf

Thibert, J. (2012). Making local planning work for urban agriculture in the North American context: A view from the ground. Journal of Planning Education and Research, 32(3), 349-357. https://doi.org/10.1177/0739456X11431692 